\title{
IRRIGATION OF A HIGH COUNTRY MACKENZIE SOIL
}

P.B. GREENWOOD and R.J. PATON

Agricultural Research Division, MA F, Oamaru

\section{Abstract}

Pasture production and water use data are presented for a border strip irrigation trial in the Upper Waitaki Basin.

Pasture development on the shallow, poorly structured Mackenzie soil was slow and irrigated pasture remained clover dominant for 6 years. With irrigation at $25 \%$ awc pasture herbage production over 3 years of this initial development stage averaged $7.2 \mathrm{t} \mathrm{DM} / \mathrm{ha} / \mathrm{yr}, 5$ times more than improved dryland pasture. Grazing days (12 - 19 month old ewes) provided during the September to April growing season were 960 under dryland conditions and 5940 under irrigation at $25 \%$ awc. Of the 3 irrigation treatments (irrigation at $0 \%, 25 \%, 50 \%$ awc), irrigating at $25 \%$ awc was the most efficient giving near-maximum pasture production and the greatest herbage response per irrigation,

Mean annual water use efficiency at $25 \%$ awc was high (63\%) and irrigation water requirement low $(470 \mathrm{~mm})$ for such a naturally, highly permeable soil and was probably due to soil compaction by earthmoving machinery during border strip preparation.

Keywords: Irrigation, high country, Mackenzie soil

\section{INTRODUCTION}

In the Upper Waitaki Basin (450 - $750 \mathrm{~m}$ asl), pasture growth is largely restricted to spring and autumn by cold winters and hot, dry summers. Improved, unirrigated pastures in much of this area are therefore of low productivity $(1.3 \mathrm{t} \mathrm{DM} / \mathrm{ha} / \mathrm{yr})$ and persistency ( 3 . 5 years; M.H. Douglas pers. comm.).

Irrigation substantially increases pasture herbage production and has been described as the key to maximising the effectiveness of dryland development (Willis 1980). Surveys of the Upper Waltaki have shown that of a total irrigable area of approximately 90,000 ha there are water resources to irrigate 20,000, 30,000 ha of suitable soils (Kerr 1979). T.H. Webb (pers. comm.) has classified the soils according to suitability for irrigation based on factors such as permeability, available rooting depth, stoniness and available water capacity.

Pasture herbage production in excess of $15 \mathrm{t}$ DM/ha/yr under irrigation and $2.5 \mathrm{t}$ DM/halyr without irrigation was measured on a deep Streamland soil by Scott \& Maunsell (1981). At the other extreme irrigation of very shallow, stony Labreck soils yielded only 3.7 - $5.7 \mathrm{t} \mathrm{DM/ha/yr} \mathrm{(Scott} \mathrm{et} \mathrm{a/} \mathrm{1982).} \mathrm{At} \mathrm{Tara} \mathrm{Hills} \mathrm{High} \mathrm{Country} \mathrm{Research}$ Station near Omarama, an irrigated shallow, stony Mackenzie soil, typically produces 9.5 t DM/ha/yr from established pasture (Greenwood unpub.)

Border strip irrigation of such soils has often been inefficient in terms of the proportion of the water applied being retained in the rooting zone of the soil (Cossens 1982, Greenwood unpub.), and must be well designed to reduce excess drainage through the permeable soil profile (T.H. Webb pers. comm.).

Pasture establishment on the stony soils in the Upper Waitakl Basin is slow and, under irrigation, pastures can remain clover dominant for many years (Scott et al 1982). It is important that this phase of pasture development be taken into account in the economic planning of irrigation schemes.

This paper reports pasture herbage production, grazing days and water use data from the development stage of a border strip irrigation trial on a shallow Mackenzie 
soil near Omarama. As part of investigations into a proposed community irrigation scheme, the trial was established to study pasture herbage production and water usage of this soil, which is representative of a large proportion of the irrigable soils in the Upper Waitaki.

\section{MATERIALS AND METHODS}

The 5.5 ha trial was on Glenbrook Station $25 \mathrm{~km}$ north of Omarama at $600 \mathrm{~m}$ asl. Mean annual rainfall over 9 years at Twizel, $10 \mathrm{~km}$ north of the trial, was $640 \mathrm{~mm}$.

The soil was a shallow Mackenzie sandy loam (T.H. Webb pers. comm.) of low natural fertility $(\mathrm{pH} 5.3, \mathrm{~K} 2, \mathrm{P} 6, \mathrm{SO} 42, \mathrm{OM} \% 1.5)$ and of variable depth due to numerous, relict stream channels. The mean stone-free soil depth was $22 \mathrm{~cm}$ underlain by $40 \mathrm{~cm}$ of very stony, loamy sand. Pasture roots were confined to the top $220 \mathrm{~mm}$ of soil which had an available water capacity of $53 \mathrm{~mm}$.

After burning the low producing native fescue tussock sward (annual herbage production $200 \mathrm{~kg} \mathrm{DM} / \mathrm{ha} / \mathrm{yr} ; \mathrm{M}$.H. Douglas pers. comm.), the area was prepared for border strip irrigation, cultivated, and sown with Nui ryegrass $(10 \mathrm{~kg} / \mathrm{ha})$, Kahu timothy (3 kg/ha), red, white and alsike clover (2 kg/ha each), in September 1977.

Following 3 years of establishment trials, 3 irrigation treatments, irrigation at $0 \%, 25 \%$ and $50 \%$ available water capacity (awc) were imposed in a 3 replicate randomised block design in 1960 . Plots received $375 \mathrm{~kg} / \mathrm{ha}$ superphosphate annually and consisted of individual, $10 \mathrm{~m}$ wide, border strips, 2 replicates being $300 \mathrm{~m}$ long and the other $200 \mathrm{~m}$.

All irrigations were conducted with a flow of $60 \mathrm{l} / \mathrm{s}$, and individual border strips were automatically irrigated with a pneumatic gate release system. Moisture levels in the $0 \cdot 300 \mathrm{~mm}$ soil depth were determined thermogravimetrically at $3 \cdot 10$ day intervals and the timing of irrigations based on these results.

Pasture herbage yield was measured at 3-weekly intervals by cutting an area of $3.7 \mathrm{~m}^{2}$ within moveable cages, to $25 \mathrm{~mm}$ height (Lynch 1966). Sward composition was determined annually by point analysis at 150 points per plot in early December.

Plots were rotationally grazed at $\mathbf{1 9 - 3 0}$ day intervals with 12-19 month old ewes. Grazing normally began in mid October and all stock were removed at the end of April. Records were kept of grazing days per plot.

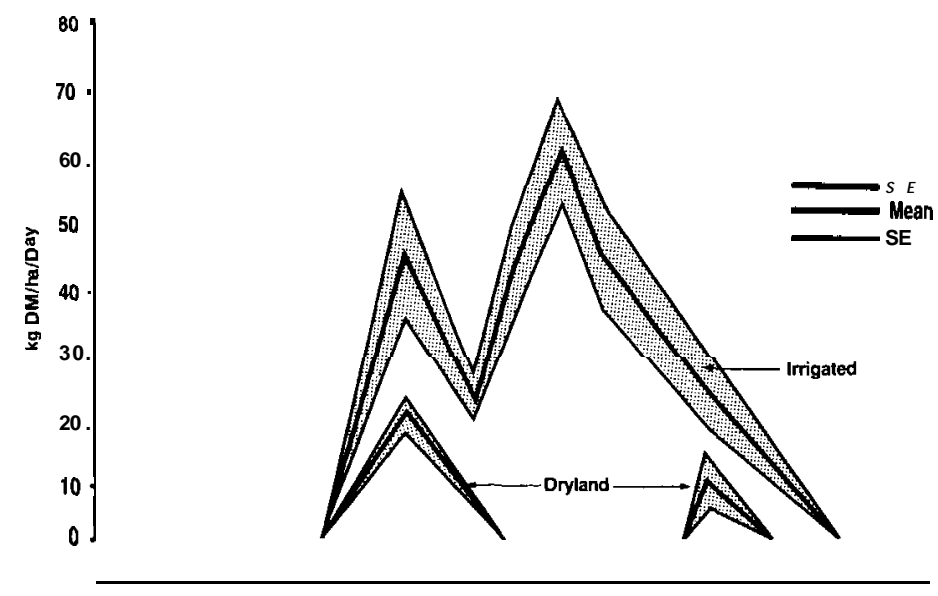

Figure 1: Rates of pasture growth for pasture irrigated at $25 \%$ awc, and for dryland pasture, 1980-83. 


\section{RESULTS AND DISCUSSION}

Growth curves for pasture irrigated at $25 \%$ awc and for dryland pasture are shown in Fig. 1. Mean herbage production, grazing days and herbage responses per irrigation and per $\mathrm{mm}$ of irrigation water for the 3 years 1980181,1982183 are given in Table 1. Dryland production given is from pasture sown in 2 border strips within the trial area but not subsequently irrigated. On Mackenzie soils in this environment dryland herbage production is likely to vary from 1 to $3 \mathrm{t} \mathrm{DM/ha/yr}$ (Scott 1979, Cossens 1982, M.H. Douglas pers. comm.).

Table 1: THE EFFECT OF IRRIGATION ON PASTURE HERBAGE YIELDS, GRAZING DAYS, AND HERBAGE RESPONSES PER IRRIGATION AND PER $\mathrm{mm}$ OF IRRIGATION WATER APPLIED.

\begin{tabular}{|c|c|c|c|c|c|c|c|}
\hline & \multirow[b]{2}{*}{ Spring } & \multicolumn{3}{|c|}{$\begin{array}{l}\text { Pasture Herbage Yield } \\
\text { (t DM/ha) }\end{array}$} & \multirow[t]{2}{*}{$\begin{array}{l}\text { Grazing days } \\
\text { (Sep - Apr) }\end{array}$} & \multicolumn{2}{|c|}{$\begin{array}{c}\text { Herbage Response } \\
\text { (kg DM) }\end{array}$} \\
\hline & & Summer & Autumn & Annual & & $\begin{array}{c}\text { Per } \\
\text { irrigation }\end{array}$ & $\begin{array}{c}\text { Per mm } \\
\text { Water } \\
\text { Applied }\end{array}$ \\
\hline \multicolumn{8}{|c|}{ Irrigation treatment } \\
\hline $25 \%$ awc (4.3)' & $8.6 \overline{3}$ & 2.60 & 0.83 & 3.20 & 5940 & 830 & 12.6. \\
\hline $\begin{array}{l}50 \% \text { awc }(9.0 \\
\text { Dryland }\end{array}$ & $\begin{array}{l}2.38 \\
1.13\end{array}$ & $\begin{array}{l}4.20 \\
0.03\end{array}$ & $\begin{array}{l}1.04 \\
0.20\end{array}$ & $\begin{array}{l}7.62 \\
1.36\end{array}$ & $\begin{array}{r}6330 \\
960\end{array}$ & $\begin{array}{c}700 \\
-\end{array}$ & $\begin{array}{r}8.9 \\
-\end{array}$ \\
\hline SED & 0.09 & 0.27 & 0.08 & 0.37 & 230 & 52 & 0.6 \\
\hline
\end{tabular}

1 Mean annual number of irrigations

\section{Dryland herbage productlon}

Dryland pasture which provided 960 grazing days from September to April produced $83 \%$ of the annual yield during spring and $15 \%$ in autumn. Summer growth was negligible (2\%). In the dryland plots, the frequency of occurrence of clover diminished during 1980 to 1983 from $43 \%$ to $15 \%$ and ryegrass from $10 \%$ to $1 \%$ while other species (mainly sweet vernal and hairgrass) increased from $24 \%$ to $49 \%$ and bare ground from $23 \%$ to $35 \%$.

\section{Irrigated herbage production}

Irrigated pasture was slow to establish and remained clover dominant until the end of the 1982183 season, 6 years after sowing. Over the 3 year period studied, frequencies of occurrence of pasture species in the irrigated plots were: clover $53 \%$, ryegrass $18 \%$, other species (mainly timothy, sweet vernal, red and alsike clovers) $17 \%$, bare ground $12 \%$. The 6 year period of clover dominance was similar to that reported by Scott (1982) on a stonier soil in the Mackenzie Basin. Because of the long period involved clover dominance is an important feature in the development of irrigated pastures on the soils studied.

Pasture irrigated at $25 \%$ awc produced 5.3 times more dry matter, and provided an extra 4990 grazing days over the growing season than the dryland pasture. Annual variability in dryland yield between years indicates that increases with irrigation of from 2.4 to 7.2 times can be expected. On similar soils in Central Otago increases of 2.5 4 times have been achieved from mature pasture (Cossens \& Radcliffe, 1974), and on a deep soil in the Mackenzie Basin increases of $2 \cdot 3.5$ times were gained (Scott \& Maunsell 1981).

Irrigation reduced the marked spring and autumn seasonality of dryland growth but the pattern of irrigated growth reflected the clover dominance and low grass 
content of the sward (Fig. 1). Grass production peaked in spring but was insufficient to maintain a high level of production through to summer when clover growth was vigorous. Approximately 35\% of annual production occurred in the spring, $50 \%$ in the summer and $15 \%$ in the autumn. Nevertheless, although irrigation resulted in large increases in production and extended the growing season through the summer and by an extra month at the end of autumn, the growing season was still short with no growth for at least 4 months during the cold period starting from mid to late May.

Increased irrigation frequency, from $0 \%$ awc to $25 \%$ awc required an additional 2 irrigations, significantly increased spring and summer herbage production, and raised annual herbage production by $40 \%$ (Table 1). Consequently there were an extra 1200 grazing days at the $25 \%$ awc irrigation treatment over the growing season. Because of the large difference in herbage yields and the small number of extra irrigations involved between the $0 \%$ awc and $25 \%$ awc treatments, the best herbage response to irrigation (in $\mathrm{kg}$ DM per irrigation) was obtained from the $25 \%$ awc treatment. The response was considerably greater than recorded on similar soils in Central Otago (Cossens 1982) and on stony Eyre and Lismore soils in Canterbury (Hayman \& McBride 1979). As in both Central Otago and Canterbury irrigating at $50 \%$ awc yielded little extra annual production ( $6 \%$ over $25 \%$ awc) in spite of a requirement for a further 3 irrigations annually. Although summer accounted for 2 of the 3 extra irrigations, and summer production increased by $17 \%$, a reduction in early spring growth precluded any significant increase in annual yield over $25 \%$ awc. Nitrogen availability in early spring, may have been reduced by increasing leaching during the previous season, resulting in poorer early spring growth.

The extra herbage produced over and above dryland production per $\mathrm{mm}$ of irrigation water applied clearly illustrates the diminishing returns from increases in irrigation frequency. Although highest returns were gained from minimal irrigation, irrigating at $25 \%$ awc still gave comparatively good returns. Irrigating on average 9 times per season at 50\% awc gave 33\% less herbage per unit of water applied.

Water use efficiency

Mean irrigation data for the 1981182 - 1982183 seasons are summarised in Table 2.

Water use efficiencies were calculated as

$\%$ efficiency $=$ water retained in the root zone of soil $\times 100$

\section{water applied}

Mackenzie soils are channelled with numerous former stream channels and are rapidly permeable. Accordingly they require careful irrigation design (i.e. flow rate, border strip level and length) to minimise wastage of water through deep percolation losses (T.H. Webb pers. comm.). Most border strip irrigation systems on similar soils near Omarama have given high water requirements and low water use efficiencies (Greenwood unpub.). In Central Otago, border strip irrigation of a Molyneaux soil, the properties of which are vey similar to Mackenzie soils, gave high water usage, and a mean water use efficiency over 12 years of only 34\% (Cossens 1982). However, in the present study small amounts of water could be applied quite efficiently although this was influenced by both border strip length and irrigation treatment. Increasing irrigation frequency which led to higher water usage, reduced efficiency. At $0 \%$ awc a very high water use efficiency $(94 \%)$ was achieved mainly because pastures were normally shorter than on the $25 \%$ awc and $50 \%$ awc treatments (mean pasture length at irrigation $25 \mathrm{~mm}$ at $0 \%$ asw, $38 \mathrm{~mm}$ at $25 \%$ and $50 \%$ awc) resulting in faster irrigation times and less deep percolation losses. Furthermore, the drier soil was able to retain more of the water applied. At the $25 \%$ and $50 \%$ awc frequencies, although similar amounts of water were applied at each irrigation, irrigating at $25 \%$ awc was $23 \%$ more water efficient than at $50 \%$ awc. Again this was because the drier soil was able to retain more of the applied water. 
Table 2: EFFECT OF IRRIGATION TREATMENT AND BORDER STRIP LENGTH ON WATER APPLICATION AND WATER USE EFFICIENCY, 1981-83.

\begin{tabular}{|c|c|c|c|}
\hline & \multicolumn{2}{|c|}{ Irrigation Water Applied } & \multirow{2}{*}{$\begin{array}{c}\text { Water Use } \\
\text { Efficiency } \\
(\%)\end{array}$} \\
\hline & $\begin{array}{c}\text { Per Irrigation } \\
(\mathbf{m m})\end{array}$ & $\begin{array}{c}\text { Annual } \\
(\mathrm{mm})\end{array}$ & \\
\hline Irrigation treatment & & & \\
\hline $0 \%$ awc & 62 & 277 & 94 \\
\hline $25 \%$ awc & 71 & 471 & 63 \\
\hline $50 \%$ awc & 72 & 685 & 40 \\
\hline SED & 5 & 36 & 5 \\
\hline Border Strip Length & & & \\
\hline $200 \mathrm{~m}$ & 59 & 422 & 74 \\
\hline $300 \mathrm{~m}$ & 73 & 506 & 62 \\
\hline
\end{tabular}

Although it was not included in the trial as a replicated treatment, the effect of border strip length is quite evident. Irrigation of the longer $300 \mathrm{~m}$ strips required, on average, a further $85 \mathrm{~mm}$ of water per season and gave water use efficiencies $12 \%$ lower than did irrigation of the $200 \mathrm{~m}$ strips.

A mean water application of approximately $70 \mathrm{~mm} /$ irrigation at $25 \%$ and $50 \%$ awc was considerably lower than that achieved on a similar soil in Central Otago (100 $\mathrm{mm}$ : Cossens 1982) or on stony Lismore soils in Canterbury $(90 \cdot 100 \mathrm{~mm}$; A.R. Taylor pers. comm.). As a result the water use efficiency achieved in the Mackenzie was significantly higher than in Central Otago and compared favourably with that normally attained in Canterbury.

Over a 12 year period on the Central Otago soil, efficient irrigation was difficult to achieve, as with a gradually increasing water infiltration rate, the depth of water applied per irrigation nearly doubled over that time (Cossens 1982). This was attributed to a gradual reduction in soil bulk density from an initial compact state, and an apparent soil loss through deep percolation. In the present study border strip preparation resulted in a similarly compacted soil (Jan. 1982 dry bulk densities, 0-220 $\mathrm{mm}$ soil depth; $1.5 \mathrm{~g} / \mathrm{cc}$ in irrigated plots, $1.0 \mathrm{~g} / \mathrm{cc}$ under surrounding virgin tussock), and led to a reduced water infiltration rate. The saturated infiltration rates measured by the double ring technique (Griffiths 1975) were $20 \mathrm{~mm} / \mathrm{hr}$ in the irrigated plots and $90 \mathrm{~mm} / \mathrm{hr}$ under the surrounding virgin tussock. Soil compaction was probably the major factor influencing water application depths and water use efficiencies. Consequently the low quantities of water applied and high efficiencies achieved must be interpreted with caution. It is likely that, in the future as occurred in Central Otago, the irrigation water requirement may significantly increase and water use efficiency decrease.

\section{CONCLUSIONS}

1. Following border strip preparation, establishment of irrigated pasture on shallow stony Mackenzie soils is slow. It is important therefore that in the economic planning of irrigation of these soils account be taken of the productivity of clover dominant pasture. This stage of development when herbage production is likely to be considerably lower than that from a fully developed grass/clover sward may last for many years. In the present study it lasted 6 years from sowing.

2. Clover dominant pastures irrigated at $25 \%, 50 \%$ awc on Mackenzie soils in the Upper Waitaki Basin produce, on average, 7.0 $7.5 \mathrm{t} \mathrm{DM} / \mathrm{ha} / \mathrm{yr}$. This represents an 
increase in production over improved dryland pasture of approximately 3-5 times.

3. Irrigation at $25 \%$ awc is the most efficient as it gives near maximum irrigated pasture production and herbage produced per $\mathrm{mm}$ of water applied, and the highest herbage response per irrigation.

4. Because of soil compaction during border strip formation, irrigation of shallow, poorly structured and highly permeable high country soils can be very water efficient for many years after initial development. However, water use efficiency is likely to gradually decrease with time.

\section{ACKNOWLEDGEMENTS}

J.M. and T.G. Kelland for kindly allowing the use of their land and stock.

\section{REFERENCES}

Cossens, G.G. 1982. Invermay Agricultural Research Centre, Technical Report 11. MAF.

; Radcliffe, J.E. 1974. N.Z. J. exp. Agric. 2: 349-58.

Griffiths, E. 1975. N.Z. Soil Bureau Scientific Report 22. DSIR.

Hayman, J.M; McBride, S.D. 1979. Proc. Agron. Soc. N.Z. 9: 121-4.

Kerr, I.G.C. 1979. N.Z. Man and the Biosphere Report 3. TGMLI.

Lynch, P.B. 1966. N.Z. Department of Agriculture Bulletin 399.

Scott, D.; Clifford, P.T.P.; Archie, W.J. 1982. N.Z. J. exp. Agric. 10: 129-32.

- Maunsell, L.A. 1981. Ibid 9: 279-90.

Willis, B.H. 1980. Proc. N.Z. Irrig. Assoc. 2: 118-24. 